\title{
$\nabla$ Nanotechnology: A Curative Approach to Combat HIV-AIDS
}

\section{IJCRR}

Section: Healthcare

Sci. Journal Impact

Factor: 6.1 (2018)

ICV: 90.90 (2018)

(c) (i) (8)

Copyright@IJCRR

\section{Manoj Baghel ${ }^{1}$, Inampudi Sailaja ${ }^{2}$, Ivvala Anand Shaker ${ }^{3}$}

'Department of Biotechnology, Parul Institute of Applied Sciences, Parul University, Vadodara- 39176o, Gujarat, India; ${ }^{2}$ Department of Biochemistry, Parul Institute of Applied Sciences, Parul University, Vadodara-39176o, Gujarat, India; ${ }^{3}$ Department of Biochemistry, Parul Institute of Medical Sciences, Parul University, Vadodara-39176o, Gujarat, India.

\section{ABSTRACT}

HIV-AIDS is one of the biggest challenges of the 21st century to cure. However, in the current scenario, various antiretroviral drugs are available which makes the condition chronic rather than worse which manages to increase the survival rate. Antiretroviral drugs are manageable but the bioavailability, lower permeability; poor half-life of the drug limits the potent activity. High dose drug administration leads to higher toxicity which arrays adverse effects and develops resistance against HIV strain. Potent targeting of drugs is lacking due to its instability, chemical degradation, and tissue barrier restriction. The application of nanotechnology to anti-retroviral drug delivery holds the capacity to cure AIDS. The nanotechnology-based efficient delivery system of Nanocarrier (liposomes, dendrimers, nanoparticles, polymeric micelles, nano-emulsion, nanovesicles) plays a major role in drug delivery. Nanocarrier has revolutionized the field of pharmaceutics in the world of drug delivery. This review depicts the nano-based system which is incorporated or encased with ARV drug to increase its efficiency or effectiveness with low adverse effect to abort HIV.

Key Words: Antiretroviral drug, Nanocarrier, HIV, AIDS, Nanotechnology, Drug delivery

\section{INTRODUCTION}

Human immunodeficiency virus (HIV), the virus that causes Acquired immunodeficiency syndrome, is one of the world's most serious public health challenges. According to the statistical report of WHO (Global Health Observatory Data Repository 2018), 37.9 million people are living with HIV infection 1 from which in India, Government of India estimates that about 2.40 million Indians are living with HIV (1.93-3.04 million) with an adult prevalence of $0.25 \%$ (2017), while $83 \%$ are the in-age group $15-49$ years. This virus isolated by Gallo et al. in the USA 2, diversely knows as human cell leukaemia virus-III (HCLV-III), human T-lymphotropic virus III (HTLV-III), lymphadenopathy-associated virus (LAV), and ultimately HIV in 1986 by ICTV (International Committee on a taxonomy of virus) 3. In the late 20th century two types of HIV strain (HIV-1 and HIV-2) categorize, which each evolved from a diverge simian immunodeficiency virus (SIV). HIV-1 is the most common one dispersed across the globe while HIV-2 is more prominent in West Africa. HIV invades from the mucosal layer, damages the immune system, leaving the host body prone to infection with a wide range of bacteria, viruses, fungi, protozoa. HIV infection propagates by the transfer of body fluids due to blood transfusion, organ transplant, sexual contact, from infected mother to offspring. Sexual transmission is one of the main sources to enter into the mucosal surfaces. The female genital tract is the dominant route of heterosexual HIV transmission 4. Sexual transmission through the Rectal route is also a substantial problem that makes it more susceptible to HIV infection due to its physiology 5 . The primary targets of HIV infection are the immune cell i.e. macrophages and dendritic cells which are present in the subepithelial layer of the vagina or cervix mucosa 6 . It transmits through the semen or other biological fluids during intercourse which penetrates the stratified squamous epithelium or columnar epithelium of the vagina to infect the target cell. HIV possesses the glycoprotein called gp120 as mention in Figure 1., on the surface of the viral coat which binds to the transmembrane protein receptor CD4 or chemokine receptor CCR5, CXCR4 of the Thelper lymphocytes and infects the cell 7.

\section{Corresponding Author:}

Prof. Dr. Inampudi Sailaja, Assistant Professor, I/C.H.O.D, Department of Biochemistry, Parul Institute of Applied Science, Parul University, P. O. Limda, Waghodia - 391760, Vadodara, Gujarat, India; Email: inampudisailaja@gmail.com

ISSN: 2231-2196 (Print)

Received: 10.06 .2020
ISSN: $0975-5241$ (Online)

Revised: 08.08.2020
Accepted: 12.09 .2020
Published: 06.10 .2020 


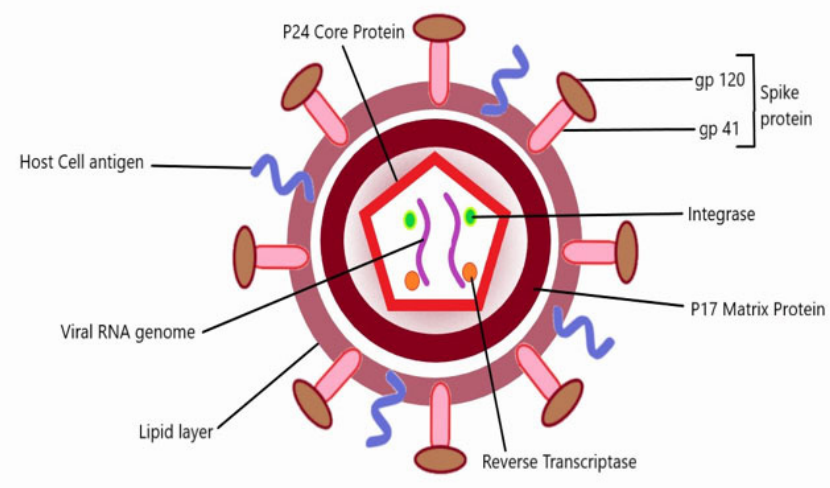

Figure 1: The structure of HIV.

The HIV infects the host cell via endocytosis it fuses with the cell membrane and releases its Viral RNA into the host cytoplasm it undergoes reverse transcription succeeded by the integration of proviral DNA into the host chromosomes. Subsequently, it creates new viral particles budding out from it to infect the other cells. It infects macrophages and depletes the amount of CD4+ cells which is the distinctive feature of the HIV infection 8. HIV Viruses utilizes different genes(a) structural genes (three) - gag, pol, and env (b) six regulatory genes - tat, rev, nef, vif, vpr, and vpu, to enhance its productivity and hijack the cellular mechanism of the host cell to generates its progeny to infect the other cells ${ }^{9,10}$. After successful infection viral particles reside into the main anatomical site such as macrophages, bone marrow, lymph node, spleen, lung, and central nervous system (CNS). When it resides in the CNS it causes significant loss of neural networks and ultimately leads to serious complications such as HIV Associated Dementia (HAD) ${ }^{[1]}$. When the patient is not treated well it will die within 5-10 years ${ }^{12}$.

In the current scenario, various Antiretroviral drugs are available in the market with a different combination which depends upon the stage of infection. High Activity Antiretroviral Therapy (HAART) is employed to treat AIDS/HIV. It had been launched in 1996 and involves a combination of at least three antiretroviral (ARV) drugs. This therapy has been used to extend the life span of HIV-infected patients ${ }^{13}$. However this therapy is used to manage the infection with some extend, but total recovery is not yet been achieved because these ARV drugs have some limitation such as moderate water solubility, low target specificity, low half-life time reactivity, poor blood-brain barrier permeability, poor bioavailability is one of the major problem ${ }^{14,15}$. The ARV drug works on the principle of blocking and inhibiting mechanisms, based on the stage of the HIV cycle. Reverse transcriptase inhibitor blocks the activity of reverse transcriptase enzyme which prevents the conversion of viral RNA to DNA. Nucleoside analogue reverse transcriptase inhibitors, including zidovudine, lamivudine, stavudine, abacavir, emtricitabine, zal- citabine, dideoxycytidine, didanosine, tenofovir disoproxil fumarate, and didanosine get to incorporate in between the nucleotide chain at the time of reverse transcription which leads to chain termination, whereas non-nucleoside analogue reverse transcriptase inhibitors, including etravirine, delavirdine, efavirenz, and nevirapine block the binding efficiency of the reverse transcriptase enzyme ${ }^{16}$. In the market, various kinds of drug regimens to treat AIDS are available or are been prescribed. But to deal with the selection of a correct combination of ARV drugs is a difficult task because due to various factors like drug properties, drug resistance status, patients' acceptance reactivity, drug costing, Drug toxicity, or any other drug adverse effect ${ }^{17}$. HAART is prescribed for a lifelong duration and any disobedience leads to a drastic increase in the viral load in the infected patient ${ }^{[18]}$. The major drawback of ARV drug is the shorter duration availability in the bloodstream of the body so that the viral particle in the site of the reservoirs like CNS, Lymph nodes, and lungs are less exposed to the drug, so to eradicate the viral particle higher doses of the drug are required for a prolonged period, which develops resistance in HIV strain ${ }^{19}$. The reservoir also contains latently infected cells which include CD4+ T-cell, monocytes/macrophages lineage which contains integrated transcription silencing provirus within their genome which can reinfect the patient due to activation of the proviral genome ${ }^{20}$. To overcome such kind of problems and limitations nano-based drug delivery system, nanomedicines and various nano approaches play a major role in the drug efficiency, drug reactivity, drug target specificity, lowering the toxicity and adverse effect of the drug and various major challenges which current ARV drug face in the current scenario.

The nanobiotechnological world which emerges out with the great advance technologies with greater efficiency due to its nanoscale mechanism ranges (1-100nm). Nanotechnology has revolutionized the field of pharmaceutics in the world of drug delivery. The basic principle is to modulate pharmacokinetics of the chemical molecule which becomes worthy to eradicate the HIV from the body without harming from its consequences. It also enhances the biodistribution and bioavailability of the drug to expose the virus particle for a prolonged period with its greater target specificity. In an enclosed nano-system that carries anti-HIV drug its absorption, excretion, distribution, and metabolism are not governed by the drug but by the physical, chemical properties of the nano-system which is based on its size and electric charge 21,22. Application of nanotechnology to ARV drug delivery holds the capacity to cure AIDS because it possibly avails the drug at the reservoir site and also increases the half-lives of the drug ${ }^{23}$. This review depicts about the nano-based system such as liposomes, dendrimers, nanoparticles, polymeric micelles, nano-emulsion, nanovesicles, and peptide self-assemble nano-drug which are incorporated or encased with ARV drug to increase its efficiency or effectiveness with low 
adverse effect to abort HIV from an infected person and also reactivate the latent HIV particle from its reservoir site to prevent further future infection.

\section{Current available strategies for the treatment of HIV- AIDS based on its life cycle}

Currently, available ARV drugs work on the principle of inhibition of the life cycle of HIV which blocks or inhibits the activity or virulence factor of the viruses. HIV viruses require the receptor molecules to enter the Host cell based on viral antigen-receptor interaction. Host cells contain a CD4 receptor molecule and one of the major co-receptor molecules (CCR5 or CXCR4) on surface ${ }^{24}$. Viral antigen called spike protein (gp120) recognizes this receptor and mediates the viral infusion with the cell membrane of the host cell with the involvement of the viral fusion protein (gp41) ${ }^{25}$. The ARV class of drug target this process to prevent the entry to the host cell. HIV entry involves three complicated processes: (1) An attachment step that requires CD4 receptor binding, (2) Coreceptor binding, (3) fusion process. Chemical or drug which acts against this process is represented inTable 1.

Table 1: Represents chemical components or drug and its description of attachment inhibitor, co-receptor binding and fusion inhibitor

\begin{tabular}{|c|c|}
\hline \multicolumn{2}{|c|}{ Attachment Inhibitors } \\
\hline $\begin{array}{l}\text { Chemical component } \\
\text { or drug }\end{array}$ & Description \\
\hline $\begin{array}{l}\text { Cyclodextrinsulfate, dex- } \\
\text { tran sulfate. }\end{array}$ & $\begin{array}{l}\text { Non-specific blocking of HIV } \\
\text { virion [26]. }\end{array}$ \\
\hline $\begin{array}{l}\text { Cyanovirin-N (CellegyP- } \\
\text { harmaceuticals) }\end{array}$ & $\begin{array}{l}\text { It binds to a conserve high man- } \\
\text { nose carbohydrate region of gp120 } \\
\text { which prevent attachment }{ }^{27} \text {. }\end{array}$ \\
\hline $\begin{array}{l}\text { PRO-2ooo (Indevus Phar- } \\
\text { maceuticals), Napthale- } \\
\text { nesulfonate polymer. }\end{array}$ & $\begin{array}{l}\text { It binds non-specifically to the } \\
C D_{4} \text { receptor to prevent interac- } \\
\text { tion of antigen and receptor. }\end{array}$ \\
\hline & (Microbicides) ${ }^{28}$. \\
\hline Glycyrrhizin. & $\begin{array}{l}\text { A triterpenoid saponin isolated } \\
\text { from liquorice root inhibits HIV-1 } \\
\text { replication by partially inhibiting } \\
\text { viral adsorption to CD } 4+\text { cells }^{29} \text {. }\end{array}$ \\
\hline $\begin{array}{l}\text { Amphotericin, lentinan, } \\
\text { suramin, aurintricarbo- } \\
\text { xylic acid, glycyrrhizin } \\
\text { sulfate. }\end{array}$ & $\begin{array}{l}\text { It interferes with the nonspecific } \\
\text { viral attachment process }{ }^{29} \text {. }\end{array}$ \\
\hline $\begin{array}{l}\text { PRO } 542 \text { (Progenic Phar- } \\
\text { maceuticals) }\end{array}$ & $\begin{array}{l}\text { Recombinant tetrameric antibody } \\
C_{4}-D_{2 G} \text { which targets the } C_{4} \\
\text { binding site on gp12o by mimick- } \\
\text { ing the } C_{4} \text { receptor }{ }^{\left[3^{\circ}\right]} \text {. }\end{array}$ \\
\hline TNX 355 & $\begin{array}{l}\text { A humanized } \mathrm{IgG}_{4} \text { monoclonal } \\
\text { antibody against } \mathrm{CD}_{4} \text {, which } \\
\text { binds to the } \mathrm{D}_{2} \text { domain of } \mathrm{CD}_{4} \\
\text { and arrest } \mathrm{CD}_{4} \text {-induced post- } \\
\text { binding conformational changes }{ }^{31} \text {. }\end{array}$ \\
\hline
\end{tabular}

CADA (cyclotriazadisulfonamide)

BMS-488043

Co-receptor binding inhibitor

AOP-RANTES and NNYRANTES

PRO-140 (Progenics Pharmaceuticals)

TAK-799, TAK-652 (Takeda Chemical Industries)

Maraviroc (MVC, UK427,857, Pfizer, Inc.),

Vicriviroc (SCH-D,

SCH-417,69o, Schering-

Plough), Ancriviroc

(SCH-C, SCH-351,125,

Schering-Plough)

KRH-1636 (Kureha Chemical Industries)

AMD310o (AnorMED, Inc., now Genzyme Corporation)

Fusion inhibitors

Enfuvirtide (T20, Fuzeon, Trimeris/Roche)

\section{TRI-999 and TRI-1144 (Trimeris)}

(Betulinylamino)alkanoic acid, C-28 aminoalkanoic acid \& its derivatives.
CADA function by a specific $\mathrm{CD}_{4}$ down-modulating potency ${ }^{[32]}$.

As a primary mode of action, it inhibits the interaction of $\mathrm{CD}_{4}$ gp120 33 .

It competes with gp12o to bind the CCR 5 co-receptor and inhibit HIV infection ${ }^{34}$.

It is a murine anti-CCR5 monoclonal antibody that binds a complex epitope

spanning multiple extracellular domains on $\mathrm{CCR}_{5}{ }^{35}$.

It inhibits the binding to $\mathrm{CCR}_{5}$ co-receptor ${ }^{36}$.

It is selective $\mathrm{CCR}_{5}$ antagonist with potent antiviral activity against all CCR5-tropic HIV-1 viruses $^{37}$.

It is an arginine-based CXCR4 antagonist with efficient anti-HIV-1 activity ${ }^{[38]}$.

It is a low molecular weight bicycle analogue with potent anti-X4 HIV variant activity ${ }^{39}$.

It is a 36-amino acid synthetic peptide that imitates the $\mathrm{HR}_{2}$ region (residues 127-162 in Cterminal) of gp41. It prevents the formation of the six-helix bundle structure that is crucial as the energy source for the fusion process $^{40}$.

TRI-999 and TRI-1144 (Trimeris) are oligopeptide fusion inhibitors $^{41}$.

It modulates antiviral fusion potency ${ }^{42}$.

After fusion to the plasma membrane, viral protein p24 gets introduced into the host cell cytoplasm ${ }^{43}$. While migrating towards the nuclear pore reverse transcription of the viral RNA takes place inside the core. Inside the viral core, RNA transformed into DNA with the help of reverse transcriptase by incorporating nucleotide triphosphates ${ }^{44}$ from the cytoplasm and ARV drug target this mechanism to combat viral DNA synthesis by blocking or terminating the process of reverse transcription. Based on this inhibition, it divided 
into two classes non-nucleoside reverse transcriptase inhibitors (NNRTI) and nucleoside reverse transcriptase inhibitors (NRTI) as shown in Table 2.

Table 2: Represents Market available Drugs and its brand name of NNRTI and NRTI.

\begin{tabular}{|c|c|c|c|}
\hline \multicolumn{4}{|c|}{$\begin{array}{l}\text { Non-nucleoside reverse transcriptase inhibitors } \\
\text { (NNRTI) }\end{array}$} \\
\hline $\begin{array}{l}\text { Generic } \\
\text { names }\end{array}$ & Abbreviations & $\begin{array}{l}\text { Brand } \\
\text { name }\end{array}$ & Manufacturer \\
\hline Efavirenz & EFV & Sustiva & $\begin{array}{l}\text { Bristol-Myers } \\
\text { Squibb }\end{array}$ \\
\hline Etravirine & $\mathrm{TMC}_{125}$ & Intelence $^{\circ}$ & Tibotec \\
\hline Nevirapine & NVP & $\begin{array}{l}\text { Vira- } \\
\text { mune }\end{array}$ & $\begin{array}{l}\text { Boehringer- } \\
\text { Ingelheim }\end{array}$ \\
\hline Delavirdine & DLV & $\begin{array}{l}\text { Rescrip- } \\
\text { tor }^{\circ}\end{array}$ & $\begin{array}{l}\text { ViiV Health } \\
\text { care. }\end{array}$ \\
\hline Rilipvirine & TMC278 & Edurant $^{\mathrm{m}}$ & Tibotec \\
\hline Doravirine & MK-1439 & Pifeltro $^{\circ}$ & Merck \& Co. \\
\hline \multicolumn{4}{|c|}{ Nucleoside Reverse transcriptase inhibitors (NRTI) } \\
\hline Didanosine & ddI & Videx & $\begin{array}{l}\text { Bristol-Myers } \\
\text { Squibb }\end{array}$ \\
\hline Zalcitabine & $\mathrm{ddC}$ & HIVID $^{\circ}$ & Roche \\
\hline Lamivudine & $3 \mathrm{TC}$ & Epivir & $\begin{array}{l}\text { GlaxoSmith- } \\
\text { Kline }\end{array}$ \\
\hline Abacavir & $\mathrm{ABC}$ & Ziagen ${ }^{\circ}$ & $\begin{array}{l}\text { GlaxoSmith- } \\
\text { Kline }\end{array}$ \\
\hline Zidovudine & AZT & Retrovir ${ }^{\circ}$ & $\begin{array}{l}\text { GlaxoSmith- } \\
\text { Kline }\end{array}$ \\
\hline Tenofovir & TDF & Vemlidy $^{\circ}$ & Gilead Sciences \\
\hline Stavudine & $\mathrm{d}_{4} \mathrm{~T}$ & Zerit $^{\circ}$ & $\begin{array}{l}\text { Bristol-Myers } \\
\text { Squibb }\end{array}$ \\
\hline Emtricitabine & FTC & Emtriva & $\begin{array}{l}\text { Bristol-Myers } \\
\text { Squibb }\end{array}$ \\
\hline Entecavir & ETV & Baraclude $^{\mathrm{ru}}$ & $\begin{array}{l}\text { Bristol-Myers } \\
\text { Squibb }\end{array}$ \\
\hline
\end{tabular}

After completion of reverse transcription viral coat deconstruct and import pro-viral DNA to the nucleus. Integrase mediates the insertion of viral DNA into the host chromosome and hijacks the cellular machinery to produce viral mRNA $^{45}$. Integrase inhibitor target this mechanism to prevent viral DNA insertion into the host. Integrase inhibitor drug represented in Table 3.
Table 3: Represents integrase inhibitors which are available in the market.

\begin{tabular}{|c|c|c|c|}
\hline \multicolumn{4}{|c|}{ Integrase inhibitors } \\
\hline $\begin{array}{l}\text { Generic } \\
\text { names }\end{array}$ & Abbreviations & $\begin{array}{l}\text { Brand } \\
\text { name }\end{array}$ & Manufacturer \\
\hline Raltegravir & RAL & Isentress $^{\circ}$ & Merck \\
\hline Dolutegravir & DTG & Tivicay ${ }^{\circ}$ & $\begin{array}{l}\text { ViiV Health } \\
\text { care. }\end{array}$ \\
\hline Elvitegravir & EVG & Vitekta & Gilead Sciences \\
\hline
\end{tabular}

After insertion of the viral DNA, it starts towards the processes of virion generation. Viral mRNA transcript translates protein and splice into mature protein by the protease ${ }^{[46]}$. Some classes of ARV drugs as follows in Table 4.which interfere's with the protease enzyme which prevents the maturation of the protein processing. Virus particles are reconstructed at the cell membrane by the recruitment of the freshly synthesized viral proteins. Two viral genomic-RNA with its enzyme and regulatory protein is packed into the viral capsid. Assembled virus particles are liberated from the cell surface by a process of budding.

Table 4: Represent protease inhibitors with its Brand name and Manufacturer.

\begin{tabular}{|c|c|c|c|}
\hline \multicolumn{4}{|c|}{ Protease inhibitors } \\
\hline $\begin{array}{l}\text { Generic } \\
\text { names }\end{array}$ & Abbreviations & $\begin{array}{l}\text { Brand } \\
\text { name }\end{array}$ & Manufacturer \\
\hline Saquinavir & SQV & Invirase $^{\circ}$ & Roche \\
\hline Atazanavir & ATV & Reyataz & $\begin{array}{l}\text { Bristol-Myers } \\
\text { Squibb }\end{array}$ \\
\hline Indinavir & IDV & Crixivan & Merck \\
\hline Nelfinavir & NFV & Viracept $^{\circ}$ & $\begin{array}{l}\text { Agouron Phar- } \\
\text { maceuticals }\end{array}$ \\
\hline Fosamprenavir & FPV & Lexiva & $\begin{array}{l}\text { ViiV Health } \\
\text { care. }\end{array}$ \\
\hline Ritonavir & RTV & Norvir ${ }^{\circ}$ & Abbvie \\
\hline Darunavir & DRV & Prezista & Abbvie \\
\hline Tipranavir & TPV & Aptivus & $\begin{array}{l}\text { Boehringer } \\
\text { Ingelheim }\end{array}$ \\
\hline Amprenavir & APV & Agenerase $^{\circ}$ & $\begin{array}{l}\text { GlaxoSmith- } \\
\text { Kline }\end{array}$ \\
\hline
\end{tabular}

Based on different stages of HIV infection, the patient receives a combinational drug treatment as shown inTable 5. , which increase the inhibitory or viricidal effect on the HIV life cycle. 
Table 5: Represents different ARV drug combination with its brand name.

\begin{tabular}{lll} 
Drug combination & Brand name $^{\circ}$ & Manufacturer \\
\hline Lopinavir + Ritonavir & Kaletra $^{\circ}$ & Abbott Labs \\
Lamivudine + Zidovudine & Combivir $^{\circ}$ & GlaxoSmithKline \\
Abacavir + Lamivudine & Trizivir $^{\circ}$ & GlaxoSmithKline \\
Tenofovir + Emtricitabine & Truvada $^{\circ}$ & Gilead Sciences \\
lamivudine + tenofovird- & Temixys $^{\circ}$ & Celltrion \\
isoproxilfumarate & & \\
\hline
\end{tabular}

\section{Nanotechnology-based drug delivery system to treat HIV- AIDS infection}

Being of nano-size the nanomaterial behaves differently than the conventional drug because due to its size reduction and have their therapeutic effect within the living system. The employment of nanotechnology platforms for the delivery of drugs is the trailblazing of medication in various areas of disease treatment ${ }^{47}$. Using nanotechnology, it's become possible to appreciate enhanced delivery of poorly water-soluble drugs, focused delivery of medicines to specific cells or tissues, and intracellular delivery of macromolecules ${ }^{48}$. Nanocarriers offer several benefits, such as the protection of drugs against degradation, drug specificity, and delivery of biological molecules, such as proteins, peptides, oligopeptides, and oligonucleotides. Nanocarriers also utilize to overcome the limitation of therapeutic applications such as drug delivery challenges, drug bioavailability, drug conformation stability, physicochemical stability, increased permeability, tissue clearance of the drug, cellular uptake, reduction of immunogenic response ${ }^{49,50}$. A brief overview of the nano-system is represented in Figure 2.

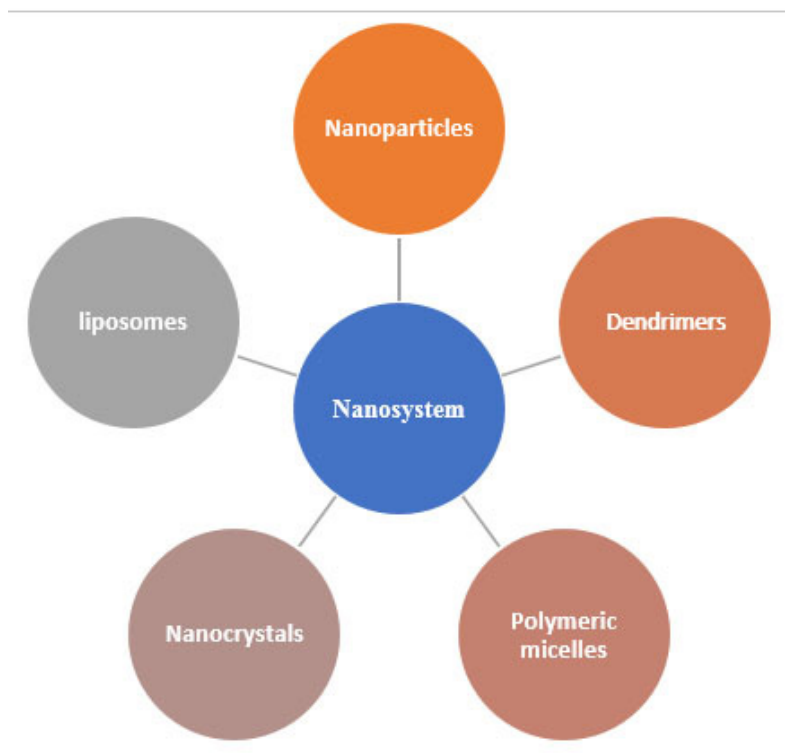

Figure 2: This pictorial art represents the diverse nano-based delivery system to treat HIV-AIDS.

\section{Liposomes}

A liposome is a small microscopic vesicle that is made up of phospholipid bilayers which are usually encircling by the aqueous core as mention in Figure 3. This is advantageous to carry hydrophilic drugs by entrapping inside the core and while the hydrophobic drug is incorporated in the lipid bilayer ${ }^{51}$.

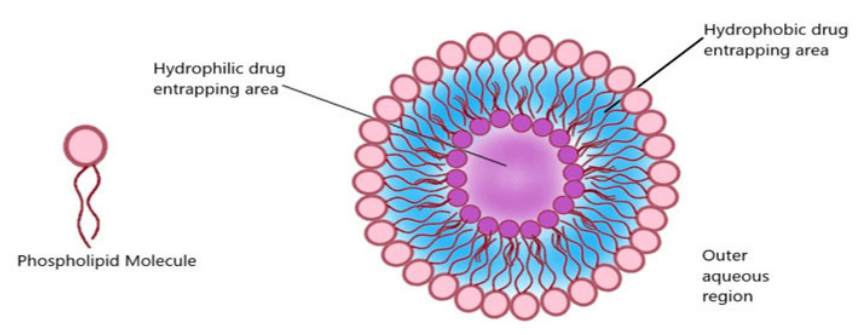

Figure 3: This picture represents the structural arrangement of liposomes.

The size of the liposomes can be $25 \mathrm{~nm}$ to several microns which gives the advantage of permeability. In their preparation, natural or synthetic phospholipids along with the cholesterol and additionally lipids, protein, or peptide fragments are used. Liposomes when entering into the living system it recognizes as the foreign particle which is engulfed by the mononuclear phagocytic cells such as macrophages, so liposomes represent favourable carrier for the anti-HIV drug to the infected cell. Thus, liposomes can enhance the efficiency of the anti-HIV drug by lowering its side effects 52 . Three types of liposomes are there which include, small uni-lamellar vesicles, large uni-lamellar vesicles, and multilamellar vesicles. In their native form liposomes are grabbed by the reticuloendothelial system and quickly clear from the circulation. This property was studied in vivo mice modal by using drug Zidovudine. The Zidovudine drug is an amphiphilic compound, with the use of a liposomal drug delivery system, it results in greater efficiency and a longer half-life in the model ${ }^{[52]}$. The liposomal loaded system of zalcitabine (2',3'-dideoxycytidine, ddc) had been studied on a mouse macrophage cell line by Makabi-Panzuet al. which shows the high intracellular uptake due to anionic charge on the liposomes ${ }^{53}$. Oussoren et al. synthesized the liposome of the phosphorylated form of zalcitabine and evaluated them in murine acquired immunodeficiency syndrome model which, arrays chemical stability, better retention entrapment, and reduced viral load in mononuclear phagocyte system in both spleen and bone marrow ${ }^{54}$. Various in vitro and in vivo studies were performed by Jain et. al. by entrapping ARV drugs such as acyclovir, indinavir, zidovudine, and lamivudine into the permuted liposomal system which shows high efficacy of transdermal flux compare to free drug. It indicates better permeability of liposomal formulation. The liposomal system of zidovudine shows 12 folds higher concentration as compared to control in 24 hours at the targeted site. There was 
higher accumulation at the reticuloendothelial organ system after the introduction of zidovudine loaded elastic liposomes trans-dermally ${ }^{55}$. Further, zidovudine loaded surface engineered liposomes were formulated by Kauret. al for lymphatic targeting. The surface of liposomes was orchestrated by the charges and site-specific ligand to intensify localization to lymphatics, prominently to lymph nodes and spleen. The engineered liposomes charged particle was created using Stearylamine, Dicetyphosphate, and mannose conjugate. Evaluating these three substances, fluorescent microscopy reveals better localization of mannose conjugate than the negative or positive charged liposomes ${ }^{56}$. Liposomes are speedily phagocytosed by the macrophages so to increase prolonged circulation time and bioavailability of the drug its surface is modified with the hydrophilic molecule such polyethene glycol. Clayton et al. created pegylated liposomes with targeting ligand derived from HIV gp120 directed monoclonal antibody F10 and demonstrated as the novel approaches to combat HIV-1. This nano-immuno-liposomes shows greater and longer antiviral activity than the free drug or drug encapsulating nontargeted liposomes ${ }^{57}$. Saiyedet al. prepared magnetic liposomes which contain azidothymidine 5'-triphosphate, the average size of these magnetic liposomes $150 \mathrm{~nm}$ it is prepared using phosphatidylcholine and cholesterol with a magnetite loading efficiency of 54\% and $45.3 \%$.It is studied to check the transmigration across an in vitro blood-brain barrier model and monocyte mediated transport by applying an external magnetic field. The outcome results in apparent permeability of magnetic azidothymidine liposomes were the 3 folds better than the free azidothymidine ${ }^{[58]}$. Dubey et al. experimented with liposomal Indinavir in the J774.A1 macrophage cell line and modified plain liposomes with covalently coupled bd-1-than-nopyranoside residues with 1,2-Bis(dimethylphosphino)ethane (DMPE) to generate mannosylated-DMPE (Man- DMPE) and further conjugated with choline and cholesterol to make upgraded mannosylated liposomes. Flow cytometric analysis reveals a better result than the plain liposomes ${ }^{59}$. Cellderived liposomes show greater and efficient targeting. It is made from the cytoplasmic membranes of the cell expressing CCR5, the human receptor for gp 120 that is mainly found on the surface of HIV infected cells and HIV-virion this exhibit significant $60 \%$ reduction in the viability in the HIV infected model cell due to binding and nullifying the infectivity ${ }^{[60]}$. The liposomes are also incorporated with the soluble-CD4, a soluble form of peptide ligand of gp120 shows efficient targeting of infected cells ${ }^{61}$. Pegylatedsaquinavir (SVQ) liposomes were less cytotoxic and sustained drug release efficiency in cell viability assay of Jurkat T- cell ${ }^{[62]}$. The immune-liposomes loaded with the Heparin-activated serine protease inhibitor antithrombin III (hep-AIII), injected into the nonhuman primate system model. The Result shows the greater than 1(10) log gradual decrease in the plasma viral load which concludes hep-AIII as salvage or alternative agent for HIV strain resistant to standard ARV drug ${ }^{63}$. Hence this critical literature review depicts how liposomes play a significant role in drug encapsulation and work as an effective nanocarrier for drug delivery for the elimination of HIV drug.

\section{Dendrimers}

A dendrimer is made up of dendrons, a small branching unit that contains interior and periphery end group, it is a polymeric nanostructure composed of several branching units in a layer by layer pattern which characterizes size, growth and the microenvironment within it, as represented in Figure 4.

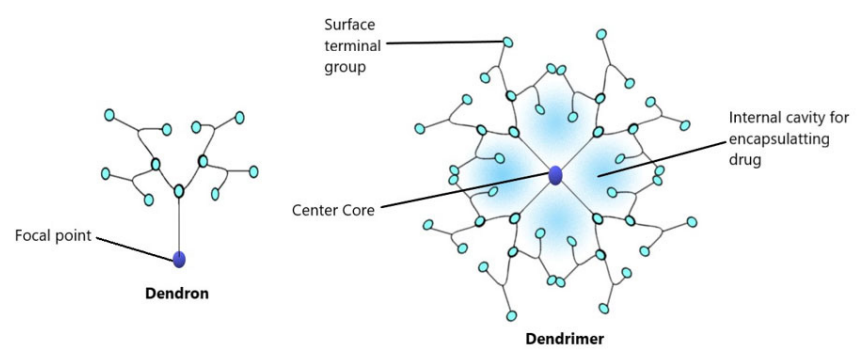

Figure 4: This picture represents the dendrimer structure with its core-shell for ARV drug entrapment.

Dendrimer contains space lying inside the dendron which can be used for the drug entrapment, targeted drug-releasing, protection against degradation from the surrounding environment, specific targeting. The size of the dendrimer is less than $100 \mathrm{~nm}$ with less polydispersity and higher functionality it is like a conventional polymer with the branched unit in 3-Dimensional architecture. The core can be synthesized by Ammonia and ethylene diamine surrounding by the highly branched repeating units such as polyether, porphyrins, poly-amido-amines, polyphenyl, and polyamine acids. The properties of the core-shell are chiefly based on the multivalent surfaces which contain targeting moieties or functional group ${ }^{64,65}$ so this allows tagging ARV drugs or dendrimer itself can act as the drug after attaching synthetic functional group along with the synthetic peptide polymer which hinders with HIV viruses. A diverse array of dendrimers can be synthesized according to the biological entity such as the HIV antigen for its interaction by doing subtle modification of branching unit type, linker, dendrimer generation, moieties, and surface ${ }^{65}$. The Anti- HIV drug Efavirenz loaded with tuftsin-conjugated fifth-generation poly (propylene imine) (T5PP) dendrimer which shows the prolonged effect of a drug in $24 \mathrm{~h}$, negligible cytotoxicity, and cellular uptake 34.5 times higher than the free drug in vitro to the infected macrophages ${ }^{[66]}$. The $2 \mathrm{G}-\mathrm{NN} 16$ amino-terminated carbosilane dendrimer use to deliver siRNA to HIV infected astrocytes in vitro which shows less cytotoxicity with controlled drug release. The 2G-NN16/siRNAdendriplexes successfully cross the blood-brain barrier model revealed by in vitro transcy- 
tosis assay with bovine brain microvascular endothelial cell which shows the potential capability to cross the blood-brain barrier ${ }^{67}$. Water- stable cationic carbosilane dendrimers utilize for the drug delivery in the HepG2 cell line, it shows greater interaction with the nucleic acid by forming nanoconjugates in various $\mathrm{pH}$ ranges with a stable condition. And nanoconjugates also show a high degree transfection with an anti-HIV oligonucleotide in experimental condition ${ }^{68}$. The SPL7013 is one of the anionic dendrimers, which contain a divalent benzhydryl amine amide of L-lysine as the core with naphthalene sulfonic acid terminations. Efficacy studies with 5\% w/w SPL7013 as an aqueous gel showed that a single intravaginal dose of the formulation prevented pigtailed macaques from intravaginal (SIV) simian-human immunodeficiency virus infection ${ }^{69}$. The first dendrimer-based drug name VivaGel ${ }^{\circledR}$ has been submitted to the US FDA as an investigational novel drug which is an aqueous-based polyacrylic acid gel containing SPL7013 buffered to physiologic $\mathrm{pH}$, a nanoscale dendrimeric molecule which binds to viruses and prevents them from affecting an organism's cells as shown in $\mathrm{f}^{70}$.

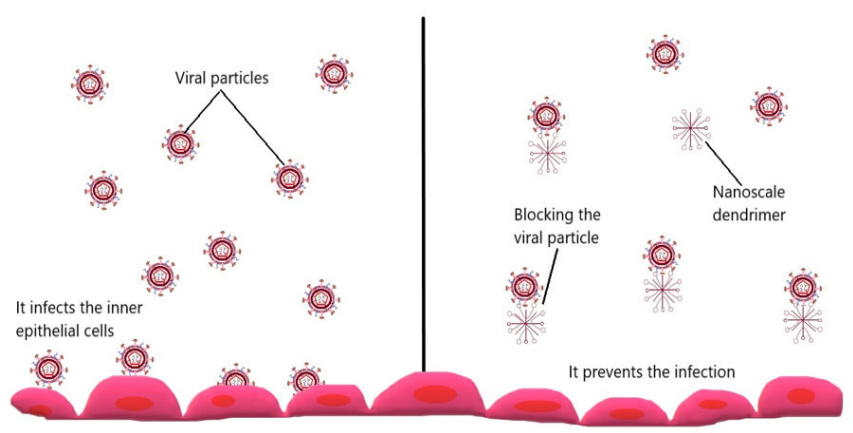

Figure 5: This pictorial art represents, one side infection of viral particle while, the other side represents the prevention of viral particle from infection with help of dendrimeric molecules.

Han et al. had generated oligosaccharide-based polylysine dendrimers with sulphated cellobiose which shows high anti-HIV activity which is comparable to dideoxycytidine, and low cytotoxicity ${ }^{71}$. Multivalent phosphorus-containing catanionic dendrimers with galactosyl ceramide analogues have an intense affinity for the V3 loop of the gp120 viral envelope protein of HIV-1 which arrays prevention of viral fusion with the plasma membrane thus acting as entry inhibitor ${ }^{72}$. Hence Dendrimer can be considered as the potent in targeted expulsion of HIV.

\section{Nanoparticles}

The nanoparticle is the microscopic colloidal particles having size ranges $(10-1000 \mathrm{~nm})^{73}$. They have the potential for specific targeting of drugs with controlled liberation, the basis on its size and polymeric composition. Nanoparticles prospects better improvement of formulation and efficacy of drugs with some physio-chemical limitation of poor stability and solubility ${ }^{74}$. Nanoparticles have increasingly experimented with targeted ARV drug delivery to achieve modulated pharmacokinetics, improved efficacy, decrease in systemic toxicity, and adverse effect. Mainly three types of nanoparticles are employed for anti-HIV curative.

\section{Polymeric nanoparticles}

A polymeric nanoparticle can be generated as per a desirable approach for targeted delivery of ARV drugs. Various polymers are used for the construction of anti- HIV polymeric nanoparticles such as poly (lactic acid) (PLA), poly (lactic-co-glycolic acid) (PLGA), poly(alkyl) cyanoacrylates,poly (ethylene glycol-co-(lactic-glycolic acid)), poly(caprolactone), and poly(methyl) methacrylate. PLA and PLGA have been approved by the FDA for human use. A diverse drug can be incorporated in these polymers based on their hydrophilicity or hydrophobicity and release characteristics can easily be modified based on the requirements ${ }^{75}$. The zidovudine loaded polyvinylpyrrolidone (PVP)/stearic acid (SA)-polyethylene glycol (PEG) nanoparticles (PSNPs) were developed by emulsification-solvent evaporation method. And studied in vitro murine neuro-2a and HeLa cells which demonstrate significantly, improvement in cellular internalization, stable colloidal suspension, better cellular uptake, increased half-life, no cytotoxicity ${ }^{76}$.

Shah and Amiji developed saquinavir-loaded poly (ethylene oxide)-modified poly(epsilon-caprolactone) (PEO-PCL) nanoparticulate system using the solvent displacement process. The cellular uptake and biodistribution of PEO-PCL were analyzed in vitro into THP-1 human monocyte/macrophage (Mo/Mac) cell line which ends in higher accumulation of drugs than the aqueous from ${ }^{77}$. The electromagnetic interference within the permeability of nanoparticles loaded SQV studied on the human brain microvascular endothelial cells. Here nanoparticles are used as poly butyl cyanoacrylate (PBCA), methyl methacrylate-sulfo-propymethacrylate (MMA-SPM) to study the blood-brain barrier human model which arrays higher permeability across the blood-brain barrier in PBCA nanoparticle than MMA-SPM nanoparticle $^{78}$. Destache et al. studied ARV drug releases from poly (DL-lactide-co-glycolide) NPs in BALB/c mice and compared with free intraperitoneal injected ARV drug such as ritonavir, lopinavir, and efavirenz on mice, which result in higher availability of the drug up to 28 days as compared to conventional one ${ }^{79}$. Furthermore, more tenofovir- loaded chitosan-based nanoparticles fashioned by the Meng et al. to maximize its mucoadhesion. By decreasing the size from $900 \mathrm{~nm}$ to $188 \mathrm{~nm}$ of nanoparticle it shows non-cytotoxicity to vaginal epithelial cell line with increased $6 \%$ to $12 \%$ mucoadhesion $^{80}$. Hence polymeric nanoparticle shows efficient drug delivery to combat HIV. 


\section{Solid lipid nanoparticles (SLN) and Nanostruc- tured lipid carriers (NCL)}

SLN are small microscopic system composed of physiological lipid which emerges to form solid nanoparticles on aqueous surfactant solution (size 50 to $10000 \mathrm{~nm}$ ). SLN offers a great opportunity to attach ARV drugs because due to its miniature size, high drug loading capacity, slow degradation of lipid matrices, large surface area reactivity ${ }^{81}$. SLN also provides sustained release minimizing drug toxicity, dosing frequency, and fluctuation in plasma drug levels ${ }^{82}$. SLN shows biphasic drug release due to is structure, initial burst due to its surface adsorption, and slow-release from its lipid core due to gradual degradation ${ }^{83}$.

SLN of protease inhibitors name atazanavir were produced by Chattopadhyay et al. to check permeability and studied on the human brain microvascular cell line (hCMEC/D3) a blood-brain barrier model which successfully results from a higher accumulation of drug by endothelial cell monolayer than the aqueous drug solution with apparent permeability across the barrier membrane ${ }^{84}$. Zidovudinepalmitateloaded SLN develops by Heiatiet al. which accommodate trilaurin as the lipid core with a combination of dimyristoyl phosphatidylglycerol which results in neutral charge. Later it is modified with polyethene glycol moieties and higher phospholipid content to the surface which results in improved plasma circulation with increases half-life of the drug ${ }^{85}$. The various modification was done to change the surface moieties of the SLN with different methods to achieve higher drug accumulation and significant permeability across the blood-brain barrier. Lopinavir SLN was modified using a hot self-nano-emulsion technique which includes a hot isotropic mixture of stearic acid, poloxamer, and polyethene glycol in water with rapid cooling which results optimize bioavailability compare to bulk lopinavir ${ }^{86}$. In perfusion experiment, a High amount of positively charged or negatively charges SLN will result into a high cortical cerebrospinal volume which loses the integrity of brain barrier in rats ${ }^{87}$ This tends to make attention that high amount of surface charges modification in SLN will increase the adverse effect on health.

NCL is the fashioned or tailored SLN with solid lipid matrix incorporated with liquid lipids with various fatty acid chain in compromised organized crystalline structure which offer higher drug accommodation capacity ${ }^{88}$. NCL is made up of low toxic lipid molecules that provide hydrolytic and oxidative stability. It also shows the biphasic drug release potential with a liquid lipophilic surface which contains drug and solid core with a higher melting point which allows drug release by diffusion and matrix erosion ${ }^{89}$. Lots of NCL have been manufactured in the current scenario to treat HIV. Advance formulated NCL, prepared by Kasongoet al., it is the mixture of Precirol ATO 5 and trans cutol loaded with didanosine nanostructured lipid car- rier manufactured using hot high-pressure homogenization method dried using liquid nitrogen and then dried material were pass through $200 \mu \mathrm{m}$ membrane which results into solid lipid particles in surfactant solution which results in high relative stability for 2 months at $25^{\circ} \mathrm{C}$ and increased encapsulation efficiency ${ }^{90,91}$. Thus, it tends for new research to investigate for effective choice of carrier to deliver the anti-HIV drug.

\section{Inorganic nanoparticles}

This class of nanoparticles includes metal elements like iron, gold, silver, titanium, and silica which nowadays employed in anti-cancer therapeutics, molecular labelling of biomarkers, theranostics approaches, bioimaging, biosensor ${ }^{92-95]}$. Nanoparticles of a noble metal such as gold, silver, and platinum have been formulated using diverse methods such as chemical bioreduction, hard template, solution-phase synthesis, Gas-phase deposition, and sol-gel ${ }^{96,97,98}$. The silver nanoparticle is getting more prominent attention due to its anti-microbial and anti-viral effects against hepatitis B, herpes simplex virus, respiratory syncytial virus, monkeypox virus, and HIV-1 in vitro including clinical isolates and resistant strains ${ }^{99-103}$ Silver nanoparticles can bind to the gp120 protein and prevent viral entry, it also inhibits the CD4 mediated viral fusion and interfere in post-entry stages of the invasion of the HIV life cycle. The Silver nanoparticles provoke higher antiviral efficiency and therapeutic index as compared to silver ion salts of sulfadiazine ${ }^{103}$.

Another potent gold nanoparticle arrays anti-HIV activity, when conjugated with the HIV inhibitors such as TAK779 and SDC-1721 which results in better anti-HIV activity than its free form. Inorganic nanoparticles possess limitations such as cytotoxicity, DNA damage, causes cellular apoptosis as evaluated by membrane leakage assay and LDH assay ${ }^{104}$. Furthermore, gene chip (microarray) analysis stipulated an induction of a large number of genes, particularly, stress associated genes coding metallothionine and heat shock protein ${ }^{105}$. So, this review suggests formulating such inorganic nanoparticles which is less toxic to the mammalian cell and must be enhanced with modified advanced hybrid technology to achieve greater efficiency.

\section{Polymeric micelles}

Polymeric micelles are the nano-engineered product of block polymer and having core-shell just like surfactant-based micelles and have been utilized for improving permeability, aqueous solubility, protection towards chemical degradation, controlled drug release, offer surface modification due to hydrophobic moieties as mention in Figure 6. 


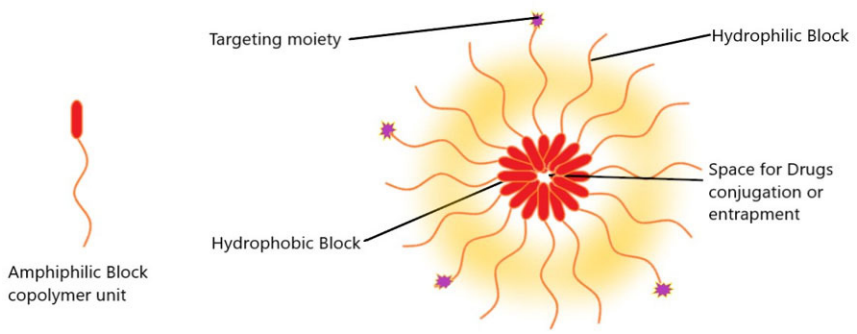

Figure 6: This pictorial representation shows polymeric nanoparticle for drug entrapment and shows targeting moieties for focused ARV drug delivery.

Polymeric micelles are architected as hydrophobic core and hydrophilic shell which allows entrapping anti-HIV drugs based on their polarity. Additionally, surface properties of polymeric micelles such as hydrophilic block can be modified by docking antibodies or another chemical ligand specific for receptors present on the diseases like HIV-AIDS ${ }^{106}$. A lot of pharmaceutical scientists has formulated polymeric micelles loaded ARV drug such as lamivudine conjugated with stearic acid-g-chitosan oligosaccharide micelles by esterification method which results in $\mathrm{pH}$-dependent drug release, low cytotoxic effect, higher cellular uptake against hepatitis B virus-infected HepG2.2.15 tumour cells ${ }^{107}$. Polymeric micelles of Efavirenz evinces significant absorption rate and 3 folds increase in the pharmacokinetic parameters of C-max values from 1789 , and $2657 \mathrm{ng} / \mathrm{ml}$ to 2856 , and $7056 \mathrm{ng} / \mathrm{ml}$ in single-dose between 20 and $80 \mathrm{mg} / \mathrm{kg}$ given to healthy adult volunteers ${ }^{108}$. Hence polymeric micelles show the greater ability for Anti-HIV drug formulation.

\section{Nanocrystals}

Nanocrystal drug itself could be a nano-size drug particle that may be disseminated in aqueous or non- aqueous media. Drug nanocrystals are often formulated using methods that supported a top-down approach or a bottom-up approach. Top-down approaches like media milling and high-pressure homogenization are the foremost preferred methods for the generation of nanocrystals because of their amenability for large-scale production. Nanocrystal drug provides longer colloidal stability, prolong, and persistent targeting due to increased surface area. Different platform technologies such as Nano-Crystal $\AA$, Nanopure $\AA$, and NANOEDGER $\AA$ have been flourished for the formulation of drug nanocrystals ${ }^{109}$. Transformation of the pure drug to nanoscale particle leads to increased parameters of pharmacokinetics, bioavailability, surface area reactivity. Nanoscale engineering of pure drugs is developed because of the intensely hydrophobic drug that is strenuous to deliver as a solution intravenously or drugs exhibiting dissolution rate-limited oral bioavailability. With the help of the media milling technique, Baret et al. formulated Rilpivirinenanocrystals of 200, 400, and $800 \mathrm{~nm}$ were injected in mice and dogs by intramuscular and intra-subcutaneous routes and their pharmacokinetic behaviour was monitored. Experimentally, all treatment results in significant detectable rilpivirine levels up to 90 days in dogs and 3 weeks in mice indicating their efficacy in long-term prophylaxis of HIV. The author's study also indicates that the intra-subcutaneous route of administration shows stable plasma concentration while intramuscular shows peak level concentration as well as higher clearance. Rilpivirine concentrations were also detected in lymphoid tissues throughout the treatment, stimulating the uptake of nanocrystals by macrophages 110,111 . Hence this review suggests that nanocrystal drugs show better potentiality to treat HIV. However, the route of administration matters in nanocrystal drug delivery.

\section{Miscellaneous- Nanoparticle utilize for (LRA) latency-reversing agents}

ARV drugs play a major role in managing the HIV infectious condition; However, it is not possible to cure HIVAIDS because due to its latency. HIV infected cells such as macrophages or monocytes which reside in the bone marrow, cerebrospinal fluids, lymph nodes which are considered as the reservoir of the human body, LRA are not able to available at this site due to its low bioavailability. Nanotechnology plays a better role in transporting LRA to the revisor site by peptide self-assemble nanoparticle loaded with Panobinostat. Panobinostat is a highly potent hydroxamic acid Histone deacetylase inhibitor that binds to the specific target of the DNA to reactivate the silenced proviral genome; it is used in the clinical development of multiple myeloma ${ }^{112}$. Experimentally it shows better blood-brain barrier permeability, effective reactivation of silenced proviral genome in vitro, increased activation of peripheral blood mononuclear cells from latently infected patients ex vivo, increased cellular drug uptake more accurate than the free Panobinostat alone. Therefore, this strategy exhibits that nanotechnology can aid to improve the activation of latent HIV, and this study lays a foundation for further enhancement of LRA delivery systems to combat silenced HIV proviral genome ${ }^{113,114}$.

\section{CONCLUSION}

In this literature review, we have discussed the potentiality of a nanotechnology-based drug delivery system to provide an empirical application for anti-HIV therapy. Nanotechnologybased system development of ARV drugs offers wide and efficient targeted drug delivery with modulated pharmacokinetics, a higher therapeutic index as demonstrated by in vitro and animals in vivo studies. These nano-systems provide prolong drug circulation, high bioavailability, drug stability, better permeability, bioaccumulation in known reservoir sites for HIV. It also demonstrated the application of ARV nanocarriers to deliver drugs across the blood-brain barrier and other tissue to kill HIV. Based on the HIV lifecycle, di- 
verse nanocarriers are surface modified with different moiety to prevent viral fusion with intended ARV drug delivery. The majority of works done in the field of nanocarrier ARV drug delivery system incorporate a single ARV agent. So, this review tends to notice about the multidrug delivery system which involves a combination of drugs can lead to tremendous efficacious treatment and downgrading of resistance profiles. Hence, nanotechnology provides a multifunctional system for scaling up therapeutic approaches with innovative formulation to fulfil diverse biological requirements.

Acknowledgement: The authors wish to express their acknowledgement to the I/C Principal TrilokAkhani PIAS, Parul University \& Dr Ivvala Anand Shaker, Professor \& HOD Dept. of Biochemistry, PIMSR, Parul University for their constant help and support throughout in preparing this manuscript. The authors are also grateful to publishers of all those articles, journals and books from where the literature for this article has been reviewed and discussed."

\section{Conflict of Interest: Nil}

\section{Source of Funding: Nil}

\section{REFERENCES}

1. WHO (Global Health Observatory Data Repository 2018). Available at:https://www.who.int/news-room/fact-sheets/detail/ hiv-aids. Accessed on March 15, 2020.

2. Gallo, R. C., Salahuddin, S. Z., Popovic, M., Shearer, G. M., Kaplan, M., Haynes, B. F., Palker, T. J., Redfield, R., Oleske, J., \&Safai, B. Frequent detection and isolation of cytopathic retroviruses (HTLV-III) from patients with AIDS and at risk for AIDS. Science (New York, N.Y.), 1984; 224(4648), 500-503.

3. De Clercq E. Anti-HIV drugs: 25 compounds approved within 25 years after the discovery of HIV. International journal of antimicrobial agents, 2009;33(4), 307-320.

4. Pauwels, R., \& De Clercq, E . Development of vaginal microbicides for the prevention of heterosexual transmission of HIV. Journal of acquired immune deficiency syndromes and human retrovirology: official publication of the International Retrovirology Association, 1996; 11(3), 211-221.

5. McGowan, I. Rectal microbicides: a new focus for HIV prevention. Sexually Transmitted Infections, 2008; 84(6), 413-417.

6. Boggiano, C., \& Littman, D. R. HIV's Vagina Travelogue. Immunity, 2007; 26(2), 145-147.

7. Littman D. R. Chemokine receptors: keys to AIDS pathogenesis. Cell, 1998; 93(5), 677-680.

8. McArthur, J. C., Brew, B. J., \&Nath, A. Neurological complications of HIV infection. The Lancet. Neurology, 2005; 4(9), 543-555.

9. Chinen, J., \& Shearer, W. T. 6. Secondary immunodeficiencies, including HIV infection. The Journal of allergy and clinical immunology, 2008;121: S388-S417.

10. Arendt, C. W.,\& Littman, D. R. HIV: Master of the host cell. Genome Biology,2001; 2(11), REVIEWS1030.

11. Vyas, T. K., Shah, L., \&Amiji, M. M. Nanoparticulate drug carriers for delivery of HIV/AIDS therapy to viral reservoir sites. Expert opinion on drug delivery,2006; 3(5), 613-628.

12. Stoddart, Cheryl \& Reyes, Richard. Models of HIV1 disease: A review of current status. Drug Discovery Today: Disease Models. 2006; 3: 113-119.

13. Lin J. H. Role of pharmacokinetics in the discovery and development of indinavir. Advanced drug delivery reviews, 1999; 39(3): 33-49.

14. Musacchio, T., \&Torchilin, V. P. Recent developments in lipidbased pharmaceutical nanocarriers. Frontiers in bioscience (Landmark edition), 2011;16: 1388-1412.

15. Mueller, B. U., Sleasman, J., Nelson, R. P., Jr, Smith, S., Deutsch, P. J., Ju, W., Steinberg, S. M., Balis, F. M., Jarosinski, P. F., Brouwers, P., Mistry, G., Winchell, G., Zwerski, S., Sei, S., Wood, L. V., Zeichner, S., \&Pizzo, P. A . A phase I/II study of the protease inhibitor indinavir in children with HIV infection. Paediatrics, 1998; 102(1 Pt 1), 101-109.

16. Rohan, L., \&Mallipeddi. Progress in antiretroviral drug delivery using nanotechnology. International Journal of Nanomedicine, 2010; 533-547.

17. Hammer, S. M., Eron, J. J., Jr, Reiss, P., Schooley, R. T., Thompson, M. A., Walmsley, S., Cahn, P., Fischl, M. A., Gatell, J. M., Hirsch, M. S., Jacobsen, D. M., Montaner, J. S., Richman, D. D., Yeni, P. G., Volberding, P. A., \& International AIDS Society-US. Antiretroviral treatment of adult HIV infection: 2008 recommendations of the International AIDS Society-USA panel. JAMA, 2008; 300(5), 555-570.

18. Richman, D. D., Margolis, D. M., Delaney, M., Greene, W. C., Hazuda, D., \& Pomerantz, R. J. The challenge of finding a cure for HIV infection. Science (New York, N.Y.), 2009; 323(5919), 1304-1307.

19. Varatharajan, L., \& Thomas, S. A. The transport of anti-HIV drugs across blood-CNS interfaces: summary of current knowledge and recommendations for further research. Antiviral Research, 2009; 82(2), A99-A109.

20. Redel, L., Le Douce, V., Cherrier, T., Marban, C., Janossy, A., Aunis, D., Van Lint, C., Rohr, O., \& Schwartz, C. HIV-1 regulation of latency in the monocyte-macrophage lineage and CD4+ T lymphocytes. Journal of leukocyte biology, 2010; 87(4), 575588.

21. Li, S. D., \& Huang, L. Pharmacokinetics and biodistribution of nanoparticles. Molecular Pharmaceutics, 2008; 5(4), 496-504.

22. LaVan, D. A., Lynn, D. M., \& Langer, R. Moving smaller in drug discovery and delivery. Nature reviews. Drug discovery. 2002; 1(1), 77-84.

23. Amiji, M. M., Vyas, T. K., \& Shah, L. K. Role of nanotechnology in HIV/AIDS treatment: the potential to overcome the viral reservoir challenge. Discovery medicine,2006; 6(34): 157-162.

24. Speck, R. F., Wehrly, K., Platt, E. J., Atchison, R. E., Charo, I. F., Kabat, D., Chesebro, B., \& Goldsmith, M. A. Selective employment of chemokine receptors as human immunodeficiency virus type 1 coreceptors determined by individual amino acids within the envelope V3 loop. Journal of virology, 1997; 71(9): 7136-7139.

25. Roux, K. H., \& Taylor, K. A. AIDS virus envelope spike structure. Current opinion in structural biology, 2007; 17(2): 244 252.

26. Callahan, L. N., Phelan, M., Mallinson, M., \& Norcross, M. A. Dextran sulfate blocks antibody binding to the principal neutralizing domain of human immunodeficiency virus type 1 without interfering with gp120-CD4 interactions. Journal of virology, 1991; 65(3): 1543-1550.

27. Boyd, M. R., Gustafson, K. R., McMahon, J. B., Shoemaker, R. H., O’Keefe, B. R., Mori, T., Gulakowski, R. J., Wu, L., Rivera, M. I., Laurencot, C. M., Currens, M. J., Cardellina, J. H., 2nd, Buckheit, R. W., Jr, Nara, P. L., Pannell, L. K., Sowder, R. C., 2nd, \& Henderson, L. E. Discovery of cyanovirin-N, a novel hu- 
man immunodeficiency virus-inactivating protein that binds viral surface envelope glycoprotein gp120: potential applications to microbicide development. Antimicrobial agents and chemotherapy, 1997 ; 41(7): 1521-1530.

28. Rusconi, S., Moonis, M., Merrill, D. P., Pallai, P. V., Neidhardt, E. A., Singh, S. K., Willis, K. J., Osburne, M. S., Profy, A. T., Jenson, J. C., \& Hirsch, M. S. Naphthalene sulfonate polymers with CD4-blocking and anti-human immunodeficiency virus type 1 activities. Antimicrobial agents and chemotherapy, 1996; 40(1): 234-236.

29. Huang, L., \& Chen, C. H. (2002). Molecular targets of anti-HIV-1 triterpenes. Current drug targets. Infectious disorders, 2002; 2(1): 33-36.

30. Allaway, G. P., Davis-Bruno, K. L., Beaudry, G. A., Garcia, E. B., Wong, E. L., Ryder, A. M., Hasel, K. W., Gauduin, M. C., Koup, R. A., \& McDougal, J. S. Expression and characterization of CD4-IgG2, a novel heterotetramer that neutralizes primary HIV type 1 isolates. AIDS research and human retroviruses, 1995; 11(5): 533-539.

31. Moore, J. P., Sattentau, Q. J., Klasse, P. J., \& Burkly, L. C. A monoclonal antibody to CD4 domain 2 blocks soluble CD4-induced conformational changes in the envelope glycoproteins of human immunodeficiency virus type 1 (HIV-1) and HIV-1 infection of CD4+ cells. Journal of virology, 1992; 66(8): 4784-4793.

32. Vermeire, K., Zhang, Y., Princen, K., Hatse, S., Samala, M. F., Dey, K., Choi, H. J., Ahn, Y., Sodoma, A., Snoeck, R., Andrei, G., De Clercq, E., Bell, T. W., \&Schols, D. (2002). CADA inhibits human immunodeficiency virus and human herpesvirus 7 replication by down-modulation of the cellular CD4 receptor. Virology, 302(2), 342-353.

33. Ho, H. T., Fan, L., Nowicka-Sans, B., McAuliffe, B., Li, C. B., Yamanaka, G., Zhou, N., Fang, H., Dicker, I., Dalterio, R., Gong, Y. F., Wang, T., Yin, Z., Ueda, Y., Matiskella, J., Kadow, J., Clapham, P., Robinson, J., Colonno, R., \& Lin, P. F. Envelope conformational changes induced by human immunodeficiency virus type 1 attachment inhibitors prevent CD4 binding and downstream entry events. Journal of virology, 2006;80(8), 4017-4025.

34. Simmons, G., Clapham, P. R., Picard, L., Offord, R. E., Rosenkilde, M. M., Schwartz, T. W., Buser, R., Wells, T. N., \&Proudfoot, A. E. Potent inhibition of HIV-1 infectivity in macrophages and lymphocytes by a novel CCR5 antagonist. Science (New York, N.Y.), 1997;276(5310), 276-279.

35. Trkola, A., Ketas, T. J., Nagashima, K. A., Zhao, L., Cilliers, T., Morris, L., Moore, J. P., Maddon, P. J., \& Olson, W. C. Potent, broad-spectrum inhibition of human immunodeficiency virus type 1 by the CCR 5 monoclonal antibody PRO 140. Journal of virology, 2001; 75(2), 579-588.

36. Seto, M., Aikawa, K., Miyamoto, N., Aramaki, Y., Kanzaki, N., Takashima, K., Kuze, Y., Iizawa, Y., Baba, M., \&Shiraishi, M. Highly potent and orally active CCR5 antagonists as anti-HIV-1 agents: synthesis and biological activities of 1-benzazocine derivatives containing a sulfoxide moiety. Journal of medicinal chemistry, 2006; 49(6), 2037-2048.

37. Dorr, P., Westby, M., Dobbs, S., Griffin, P., Irvine, B., Macartney, M., Mori, J., Rickett, G., Smith-Burchnell, C., Napier, C., Webster, R., Armour, D., Price, D., Stammen, B., Wood, A., \&Perros, M. Maraviroc (UK-427,857), a potent, orally bioavailable, and selective small-molecule inhibitor of chemokine receptor CCR5 with broad-spectrum anti-human immunodeficiency virus type 1 activity. Antimicrobial agents and chemotherapy, 2005; 49(11), 4721-4732.

38. Ichiyama, K., Yokoyama-Kumakura, S., Tanaka, Y., Tanaka, R., Hirose, K., Bannai, K., Edamatsu, T., Yanaka, M., Niitani, Y.,
Miyano-Kurosaki, N., Takaku, H., Koyanagi, Y., \& Yamamoto, N. (2003). A duodenally absorbable CXC chemokine receptor 4 antagonists, KRH-1636, exhibits a potent and selective antiHIV-1 activity. Proceedings of the National Academy of Sciences of the United States of America, 2003;100(7), 4185-4190.

39. Blanco, J., Barretina, J., Henson, G., Bridger, G., De Clercq, E., Clotet, B., \&Esté, J. A. The CXCR4 antagonist AMD3100 efficiently inhibits cell-surface-expressed human immunodeficiency virus type 1 envelope-induced apoptosis. Antimicrobial agents and chemotherapy, 2000; 44(1), 51-56.

40. Wild, C., Greenwell, T., \& Matthews, T. A synthetic peptide from HIV-1 gp41 is a potent inhibitor of virus-mediated cellcell fusion. AIDS research and human retroviruses, 1993; 9(11): 1051-1053.

41. Dwyer, J. J., Wilson, K. L., Davison, D. K., Freel, S. A., Seedorff, J. E., Wring, S. A., Tvermoes, N. A., Matthews, T. J., Greenberg, M. L., \&Delmedico, M. K. Design of helical, oligomeric HIV-1 fusion inhibitor peptides with potent activity against enfuvirtideresistant virus. Proceedings of the National Academy of Sciences of the United States of America, 2007; 104(31), 12772-12777.

42. Sun, I. C., Chen, C. H., Kashiwada, Y., Wu, J. H., Wang, H. K., \& Lee, K. H. Anti-AIDS agents 49. Synthesis, anti-HIV, and anti-fusion activities of IC9564 analogues based on betulinic acid. Journal of medicinal chemistry, 2000; 45(19): 4271-4275.

43. Klasse P. J. The molecular basis of HIV entry. Cellular microbiology, 2012; 14(8): 1183-1192.

44. Sonenberg, N., \& Hinnebusch, A. G. Regulation of Translation Initiation in Eukaryotes: Mechanisms and Biological Targets. Cell, 1999; 136(4): 731-745.

45. Maertens, G. N., Hare, S., \&Cherepanov, P. The mechanism of retroviral integration from X-ray structures of its key intermediates. Nature, 2010; 468(7321): 326-329.

46. Trkola A.HIV-host interactions: vital to the virus and key to its inhibition. Current opinion in microbiology, 2004; 7(4): 407411.

47. Farokhzad, O. C., \& Langer, R. Impact of nanotechnology on drug delivery. ACS Nano, 2009; 3(1): 16-20.

48. Kumar, L., Verma, S., Prasad, D. N., Bhardwaj, A., Vaidya, B., \& Jain, A. K. Nanotechnology: a magic bullet for HIV AIDS treatment. Artificial cells, nanomedicine, and biotechnology,2015; 43(2): 71-86.

49. Sharma, P., \&Garg, S. Pure drug and polymer-based nanotechnologies for the improved solubility, stability, bioavailability and targeting of anti-HIV drugs. Advanced drug delivery reviews, 2010; 62(4): 491-502.

50. Takeuchi, H., Yamamoto, H., \& Kawashima, Y. Mucoadhesivenanoparticulate systems for peptide drug delivery. Advanced drug delivery reviews, 2001;47(1): 39-54.

51. Sharma, A. Liposomes in drug delivery: Progress and limitations. International Journal of Pharmaceutics, 1997;154(2): 123-140.

52. Jin, S. X., Bi, D. Z., Wang, J., Wang, Y. Z., Hu, H. G., \& Deng, Y. H. Pharmacokinetics and tissue distribution of zidovudine in rats following intravenous administration of zidovudine myristate loaded liposomes. Die Pharmazie,2005; 60(11): 840-843.

53. Makabi-Panzu, B., Gourde, P., Désormeaux, A., \& Bergeron, M. G. Intracellular and serum stability of liposomal 2',3'-dideoxycytidine. Effect of lipid composition. Cellular and molecular biology (Noisy-le-Grand, France), 1998; 44(2): 277-284.

54. Oussoren, C., Magnani, M., Fraternale, A., Casabianca, A., Chiarantini, L., Ingebrigsten, R., Underberg, W. J., \& Storm, G. (1999). Liposomes as carriers of the antiretroviral agent dideoxycytidine-5' -triphosphate. International journal of pharmaceutics, 1999; 180(2): 261-270. 
55. Jain, S., Tiwary, A. K., \& Jain, N. K. Sustained and targeted delivery of an anti-HIV agent using elastic liposomal formulation: mechanism of action. Current drug delivery, 2006; 3(2): 157-166.

56. Kaur, C. D., Nahar, M., \& Jain, N. K. Lymphatic targeting of zidovudine using surface-engineered liposomes. Journal of drug targeting,2008; 16(10), 798-805.

57. Clayton, R., Ohagen, A., Nicol, F., Del Vecchio, A. M., Jonckers, T. H., Goethals, O., Van Loock, M., Michiels, L., Grigsby, J., Xu, Z., Zhang, Y. P., Gutshall, L. L., Cunningham, M., Jiang, H., Bola, S., Sarisky, R. T., \&Hertogs, K. Sustained and specific in vitro inhibition of HIV-1 replication by a protease inhibitor encapsulated in gp120-targeted liposomes. Antiviral Research, 2009; 84(2), 142-149.

58. Saiyed, Z. M., Gandhi, N. H., \& Nair, M. P Magnetic nanoformulation of azidothymidine 5'-triphosphate for targeted delivery across the blood-brain barrier. International journal of nanomedicine,2010; 5, 157-166.

59. Dubey, V., Nahar, M., Mishra, D., Mishra, P., \& Jain, N. K. Surface structured liposomes for site-specific delivery of an antiviral agent-indinavir. Journal of Drug Targeting, 2010; 19(4): 258-269.

60. Bronshtein, T., Toledano, N., Danino, D., Pollack, S., \&Machluf, M. Cell-derived liposomes expressing CCR5 as a new targeted drug-delivery system for HIV infected cells. Journal of controlled release: official journal of the Controlled Release Society, 2011; 151(2): 139-148.

61. Slepushkin, V. A., Salem, I. I., Andreev, S. M., Dazin, P., \&Düzgüneş, N. Targeting of liposomes to HIV-1-infected cells by peptides derived from the CD4 receptor. Biochemical and biophysical research communications, 1996; 227(3): 827-833.

62. Ramana, L. N., Sharma, S., Sethuraman, S., Ranga, U., \& Krishnan, U. M. Investigation on the stability of saquinavir loaded liposomes: implication on stealth, release characteristics and cytotoxicity. International journal of pharmaceutics, 2012;431(1-2): 120-129.

63. Asmal, M., Whitney, J. B., Luedemann, C., Carville, A., Steen, R., Letvin, N. L., \&Geiben-Lynn, R. In vivo anti-HIV activity of the heparin-activated serine protease inhibitor antithrombin III encapsulated in lymph-targeting immune liposomes. PloS one,2012; 7(11): e48234.

64. Gajbhiye, V., Palanirajan, V. K., Tekade, R. K., \& Jain, N. K. Dendrimers as therapeutic agents: a systematic review. The Journal of pharmacy and pharmacology,2009; 61(8): 989-1003.

65. Kharwade, R., More, S., Warokar, A., Mahajan, N \& Agrawal, P., Starburst PAPAM dendrimers: Synthetic approaches, surface modifications and biomedical application. Arab. J. Chem. 2020; 13(7): 6009-60039.

66. Bosman, A. W., Janssen, H. M., \& Meijer, E. W. About Dendrimers: Structure, Physical Properties, and Applications. Chemical Reviews, 1999; 99(7): 1665-1688.

67. Dutta, T., Garg, M., \& Jain, N. K. Targeting of efavirenz loaded tuftsin conjugated poly(propylene imine) dendrimers to HIV infected macrophages in vitro. European journal of pharmaceutical sciences: official journal of the European Federation for Pharmaceutical Sciences, 2008; 34(2-3): 181-189.

68. Jiménez, J. L., Gómez, R., Briz, V., Madrid, R., Bryszewsk, M., de la Mata, F. J., \& Muñoz-Fernández, M. Á. Carbosilanedendrimers as carriers of siRNA. Journal of Drug Delivery Science and Technology,2012; 22(1): 75-82.

69. de Las Cuevas, N., Garcia-Gallego, S., Rasines, B., de la Mata, F. J., Guijarro, L. G., Muñoz-Fernández, M. Á., \& Gómez, R. In vitro studies of water-stable cationic carbosilanedendrimers as delivery vehicles for gene therapy against HIV and hepatocarci- noma. Current medicinal chemistry, 2012; 19(29): 5052-5061.

70. Kharwade, R., More, S., Mahajan, N., Agrawal, P. Functionalised dendrimer: Potential tool for antiretroviral therapy.Curr. Nonosci. 2020; 16(5): 1-15. 10.2174/15734137166662002131 14836

71. Jiang, Y. H., Emau, P., Cairns, J. S., Flanary, L., Morton, W. R., McCarthy, T. D., \& Tsai CC. SPL7013 gel as a topical microbicide for the prevention of vaginal transmission of SHIV89.6P in macaques. AIDS research and human retroviruses, 2005; 21(3): 207-213.

72. Rupp, R., Rosenthal, S. L., \& Stanberry, L. R. VivaGel (SPL7013 Gel): a candidate dendrimer--microbicide for the prevention of $\mathrm{HIV}$ and HSV infection. International journal of nanomedicine, 2007;2(4): 561-566.

73. Han, S., Yoshida, D., Kanamoto, T., Nakashima, H., Uryu, T., \& Yoshida, T. Sulfated oligosaccharide cluster with polylysine core scaffold as a new anti-HIV dendrimer. Carbohydrate Polymers, 2010; 80(4): 1111-1115.

74. Blanzat, M., Turrin, C. O., Perez, E., Rico-Lattes, I., Caminade, A. M., \&Majoral, J. Phosphorus-containing dendrimers bearing galactosyl ceramideanalogs: self-assembly properties. Chemical communications (Cambridge, England),2002; (17): 1864-1865.

75. Panyam, J., \&Labhasetwar, V. Biodegradable nanoparticles for drug and gene delivery to cells and tissue. Advanced drug delivery reviews, 2003; 55(3): 329-347.

76. De Jaeghere, F., Allémann, E., Kubel, F., Galli, B., Cozens, R., Doelker, E., \&Gurny, R. Oral bioavailability of a poorly watersoluble HIV-1 protease inhibitor incorporated into $\mathrm{pH}$-sensitive particles: effect of the particle size and nutritional state. Journal of controlled release: official journal of the Controlled Release Society, 2000; 68(2): 291-298.

77. Mallipeddi, R., \&Rohan, L. C. Progress in antiretroviral drug delivery using nanotechnology. International journal of nanomedicine, 2010; 5: 533-547.

78. Joshy, K. S., Snigdha, S., Anne, G., Nandakumar, K., Laly. A., P., \&Sabu, T. Poly (vinyl pyrrolidone)-lipid based hybrid nanoparticles for anti-viral drug delivery. Chemistry and Physics of Lipids, 2018; 210: 82-89.

79. Shah, L. K., \&Amiji, M. M. Intracellular delivery of saquinavir in biodegradable polymeric nanoparticles for HIV/AIDS. Pharmaceutical Research, 2006; 23(11): 2638-2645.

80. KUO, Y., \& KUO, C. Electromagnetic interference in the permeability of saquinavir across the blood-brain barrier using nanoparticulate carriers. International Journal of Pharmaceutics, 2008; 351(1-2): 271-281.

81. Destache, C. J., Belgum, T., Goede, M., Shibata, A., \&Belshan, M. A. Antiretroviral release from poly (DL-lactide-co-glycolide) nanoparticles in mice. Journal of Antimicrobial Chemotherapy, 2010; 65(10): 2183-2187.

82. Meng, J., Sturgis, T. F., \&Youan, B. B. Engineering tenofovir loaded chitosan nanoparticles to maximize microbicide mucoadhesion. European journal of pharmaceutical sciences: official journal of the European Federation for Pharmaceutical Sciences, 2011; 44(1-2): 57-67.

83. Rawat, M., Singh, D., Saraf, S., \&Saraf, S. Lipid carriers: a versatile delivery vehicle for proteins and peptides. Yakugakuzasshi: Journal of the Pharmaceutical Society of Japan, 2008; 128(2): 269-280.

84. Martins, S., Sarmento, B., Ferreira, D. C., \&Souto, E. B. Lipid-based colloidal carriers for peptide and protein delivery-liposomes versus lipid nanoparticles. International journal of nanomedicine, 2007;2(4): 595-607.

85. Chattopadhyay, N., Zastre, J., Wong, H. L., Wu, X. Y., \&Bendayan, R. Solid lipid nanoparticles enhance the delivery of the 
HIV protease inhibitor, atazanavir, by a human brain endothelial cell line. Pharmaceutical Research, 2008; 25(10): 2262-2271.

86. Heiati, H., Tawashi, R., \& Phillips, N. C. (1998). Solid lipid nanoparticles as drug carriers. International Journal of Pharmaceutics, 1998; 174(1-2): 71-80.

87. Negi, J. S., Chattopadhyay, P., Sharma, A. K., \& Ram, V. Development of solid lipid nanoparticles (SLNs) of lopinavir using hot self-nano-emulsification (SNE) technique. European journal of pharmaceutical sciences: official journal of the European Federation for Pharmaceutical Sciences, 2013; 48(1-2): 231-239.

88. Lockman, P. R., Koziara, J. M., Mumper, R. J., \& Allen, D. D. Nanoparticle surface charges alter blood-brain barrier integrity and permeability. Journal of drug targeting, 2004;12(9): 635641.

89. Abbasalipourkabir, R., Salehzadeh, A., \& Abdullah, R. Characterization and stability of nanostructured lipid carriers as drug delivery system. Pakistan journal of biological sciences: PJBS, 2012; 15(3): 141-146.

90. Zhang, X., Liu, J., Qiao, H., Liu, H., Ni, J., Zhang, W., \& Shi, Y. (2010). Formulation optimization of dihydroartemisinin nanostructured lipid carrier using response surface methodology. Powder Technology, 2010; 197(1-2): 120-128.

91. Kasongo, K. W., Jansch, M., Müller, R. H., \& Walker, R. B. Evaluation of the in vitro differential protein adsorption patterns of didanosine-loaded nanostructured lipid carriers (NLCs) for potential targeting to the brain. Journal of liposome research, 2011; 21(3): 245-254.

92. Kuo, Y. C., \& Chung, C. Y. Transcytosis of CRM197-grafted poly butyl cyanoacrylate nanoparticles for delivering zidovudine across human brain microvascular endothelial cells. Colloids and surfaces. B, Biointerfaces, 2012;91: 242-249.

93. Porcel, E., Liehn, S., Remita, H., Usami, N., Kobayashi, K., Furusawa, Y., Le Sech, C., \& Lacombe, S. Platinum nanoparticles: a promising material for future cancer therapy.Nanotechnology, 2010;21(8): 85103.

94. Jain K. K. Nano diagnostics: application of nanotechnology in molecular diagnostics. Expert review of molecular diagnostics, 2003; 3(2): 153-161.

95. Wang, J., Wang, L., Sun, Y., Zhu, X., Cao, Y., Wang, X., Zhang, H., \& Song, D. Surface plasmon resonance biosensor based on $\mathrm{Au}$ nanoparticle in titania sol-gel membrane. Colloids and surfaces. B, Biointerfaces, 2010;75(2): 520-525.

96. Jokerst, J. V., Cole, A. J., Van de Sompel, D., \&Gambhir, S. S. Gold nanorods for ovarian cancer detection with photoacoustic imaging and resection guidance via Raman imaging in living mice. ACS nano, 2012;6(11): 10366-10377.

97. Zhou, Y., Yu, S. H., Cui, X. P., Wang, C. Y., \& Chen, Z. Y. Formation of Silver Nanowires by a Novel Solid-Liquid Phase Arc Discharge Method. Chemistry of Materials, 1999;11(3): 545-546.

98. Ladj, R., Bitar, A., Eissa, M., Mugnier, Y., Le Dantec, R., Fessi, H., \& Elaissari, A.. Individual inorganic nanoparticles: preparation, functionalization and in vitro biomedical diagnostic applications. Journal of Materials Chemistry B, 2013; 1(10), 1381.

99. Canizal, G., Ascencio, J. A., Gardea-Torresday, J., \&Yacamán, M. J. Journal of Nanoparticle Research, 2001; 3(5/6): 475-481.

100. Lu, L., Sun, R. W., Chen, R., Hui, C. K., Ho, C. M., Luk, J. M., Lau, G. K., \&Che, C. M. Silver nanoparticles inhibit hepatitis B virus replication. Antiviral therapy, 2008; 13(2): 253-262.

101. Baram-Pinto, D., Shukla, S., Perkas, N., Gedanken, A., \& Sarid, R. Inhibition of herpes simplex virus type 1 infection by silver nanoparticles capped with mercapto ethane sulfonate. Bioconjugate Chemistry, 2009; 20(8): 1497-1502.
102. Sun, Lova \& Singh, Ankur \&Vig, Komal \& Pillai, Shreekumar \& Singh, Shree. (2008). Silver Nanoparticles Inhibit Replication of Respiratory Syncytial Virus. Journal of Biomedical Nanotechnology. 2008;4: 149-158.

103. Rogers, J. V., Parkinson, C. V., Choi, Y. W., Speshock, J. L., \&Hussain, S. M. (2008). A Preliminary Assessment of Silver Nanoparticle Inhibition of Monkeypox Virus Plaque Formation. Nanoscale Research Letters, 2008;3(4): 129-133.

104. Lara, H. H., Ayala-Nuñez, N. V., Ixtepan-Turrent, L., \& Rodriguez-Padilla, C. (2010). Mode of antiviral action of silver nanoparticles against HIV-1. Journal of nanobiotechnology, 2010; $8: 1$.

105. Braydich-Stolle, L., Hussain, S., Schlager, J. J., \& Hofmann, M. C. (2005). In vitro cytotoxicity of nanoparticles in mammalian germline stem cells. Toxicological sciences: an official journal of the Society of Toxicology, 2005;88(2): 412-419.

106. Kawata, K., Osawa, M., \& Okabe, S. In vitro toxicity of silver nanoparticles at noncytotoxic doses to HepG2 human hepatoma cells. Environmental science \& technology, 2009;43(15), 6046-6051.

107. Nagasaki, Y., Yasugi, K., Yamamoto, Y., Harada, A., \&Kataoka, K. (2001). Sugar-installed block copolymer micelles: their preparation and specific interaction with lectin molecules. Biomacromolecules, 2001;2(4): 1067-1070.

108. Li, Q., Du, Y. Z., Yuan, H., Zhang, X. G., Miao, J., Cui, F. D., \& Hu, F. Q. (2010). Synthesis of lamivudine stearate and antiviral activity of stearic acid-g-chitosan oligosaccharide polymeric micelles delivery system. European journal of pharmaceutical sciences: official journal of the European Federation for Pharmaceutical Sciences, 2010;41(3): 498-507.

109. Chiappetta, D. A., Hocht, C., Taira, C., \&Sosnik, A. (2011). Oral pharmacokinetics of the anti-HIV efavirenz encapsulated within polymeric micelles. Biomaterials, 2011;32(9): 2379-2387.

110. Desai, P. P., Date, A. A., \&Patravale, V. B. (2012). Overcoming poor oral bioavailability using nanoparticle formulations - opportunities and limitations. Drug Discovery Today: Technologies, 2012; 9(2): e87-e95.

111. Baert, L., van 'tKlooster, G., Dries, W., François, M., Wouters, A., Basstanie, E., Iterbeke, K., Stappers, F., Stevens, P., Schueller, L., Van Remoortere, P., Kraus, G., Wigerinck, P., \& Rosier, J. Development of a long-acting injectable formulation with nanoparticles of rilpivirine (TMC278) for HIV treatment. European journal of pharmaceutics and biopharmaceutics: official journal of Arbeitsgemeinschaft fur PharmazeutischeVerfahrenst echnike.V, 2009; 72(3): 502-508.

112. van 'tKlooster, G., Hoeben, E., Borghys, H., Looszova, A., Bouche, M. P., van Velsen, F., \&Baert, L. (2010). Pharmacokinetics and disposition of rilpivirine (TMC278) nanosuspension as a long-acting injectable antiretroviral formulation. Antimicrobial agents and chemotherapy, 2010; 54(5): 2042-2050.

113. Manson McManamy, M. E., Hakre, S., Verdin, E. M., \& Margolis, D. M. Therapy for latent HIV-1 infection: the role of histone deacetylase inhibitors. Antiviral chemistry \& chemotherapy,2014: 23(4): 145-149.

114. Kuai, Q., Wang, Y., Gao, F., Qi, Y., Wang, R., Wang, Y.,Yu, Q. Peptide Self-Assembly Nanoparticles Loaded with Panobinostat to Activate Latent Human Immunodeficiency Virus. Journal of Biomedical Nanotechnology, 2019;15(5): 979-992. 